JPL D-2185

Issue 2

\title{
SP.100 PROGRAM
}

\section{Users Handbook} Basic Configurational Tradeoffs

Ram Manvi and Toshio Fujita

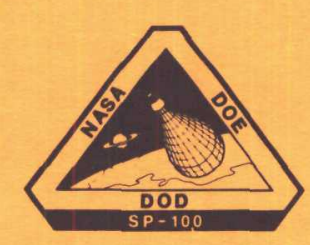

15 March 1986

National Aeronautics and Space Administration

Jet Propulsion Laboratory

California Institute of Technology

Pasadena, California 


\section{DISCLAIMER}

This report was prepared as an account of work sponsored by an agency of the United States Government. Neither the United States Government nor any agency Thereof, nor any of their employees, makes any warranty, express or implied, or assumes any legal liability or responsibility for the accuracy, completeness, or usefulness of any information, apparatus, product, or process disclosed, or represents that its use would not infringe privately owned rights. Reference herein to any specific commercial product, process, or service by trade name, trademark, manufacturer, or otherwise does not necessarily constitute or imply its endorsement, recommendation, or favoring by the United States Government or any agency thereof. The views and opinions of authors expressed herein do not necessarily state or reflect those of the United States Government or any agency thereof. 


\section{DISCLAIMER}

Portions of this document may be illegible in electronic image products. Images are produced from the best available original document. 


\section{SP.100 PROGRAM}

\section{Users Handbook Basic Configurational Tradeoffs}

Ram Manvi and Toshio Fujita

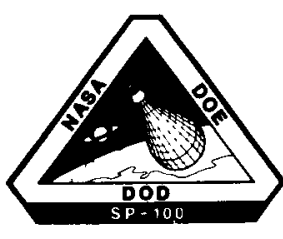

15 March 1986

National Aeronautics and Space Administration

Jet Propulsion Laboratory

California Institute of Technology

Pasadena, California

\section{DISCLAIMER}

This report was prepared as an account of work sponsored by an agency of the United States Government. Neither the United States Government nor any agency thereof, nor any of their employees, makes any warranty, express or implied, or assumes any legal liability or responsibility for the accuracy, completeness, or usefulness of any information, apparatus, product, or process disclosed, or represents that its use would not infringe privately owned rights. Reference herein to any specific commercial product, process, or service by trade name, trademark, manufacturer, or otherwise does not necessarily constitute or imply its endorsement, recommendation, or favoring by the United States Government or any agency thereof. The views and opinions of authors expressed herein do not necessarily state or reflect those of the United States Government or any agency thereof.

\section{MASTEP}




\section{Typical SP-100 Reference Design}

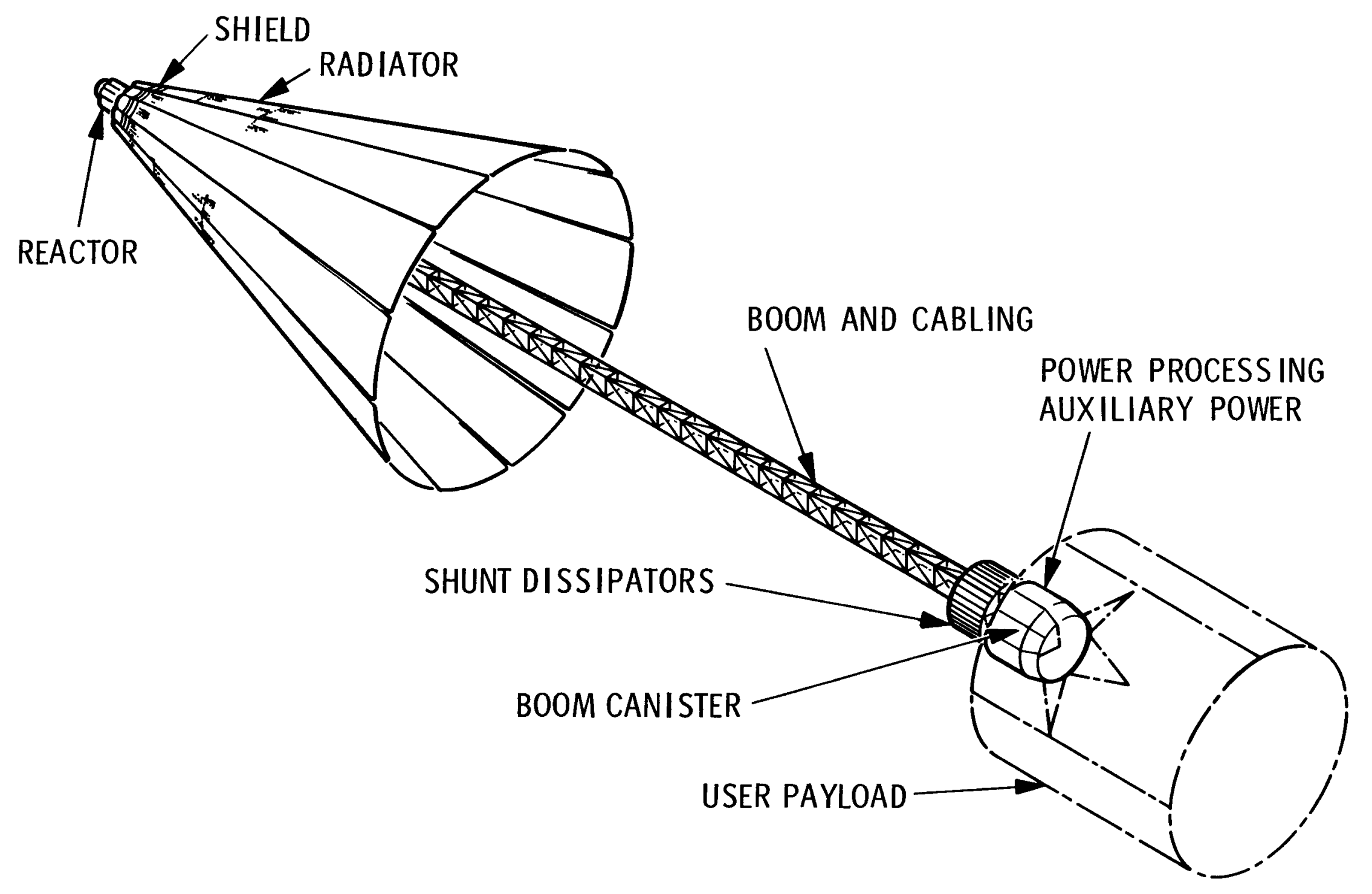


THIS DOCUMENT ADDRESSES BASIC CONFIGURATIONAL TRADEOFFS ASSOCIATED WITH THE SP-100 Class of NuClear space POWER SYStems. IN the SP-100 PROJEct, THE THREE REFERENCE DESIGNS, FALLBACK, BASELINE, AND ADVANCED, EMPLOY THERMOELECTRIC POWER CONVERSION WITH DIFFERENT THERMOELECTRIC MATERIALS •

THIS ISSUE OF THE DOCUMENT PRESENTS RESULtS GENERATED fOR THE THERMOELECTRIC DESIGN AS OF THE END OF 1985. EMPHASIS IS PLACED ON SHOWING GENERAL TRENDS AND THE RANGE OF POSSIBILITIES THAT COULD RESULT FROM SELECTION OF A PARTICULAR DESIGN. THIS DOCUMENT, WHICH REFLECTS EFFORTS ON 100-KWE REFERENCE DESIGNS AS OF THE END OF 1985, WILL BE EXTENDED AND UPDATED TO REFLECT PROGRESS IN THE DESIGN STUDIES OF THE FOLLOW-ON GROUND ENGINEERING PHASE FOR WHICH A 300-KWE SIZE HAS BEEN SELECTED.

THERE IS CONSIDERABLE FLEXIBILITY TO THE SP-100 POWER SYSTEM SO THAT IT WILL GENERALLY BE MOST ADVANTAGEOUS TO TAILOR IT TO MEET USER REQUIREMENTS.

THIS DOCUMENT IS INTENDED tO ALLOW POTENTIAL USERS TO DETERMINE THE SP-100 CONFIGURATION THAT MATCHES THEIR APPLICATION SYSTEM REQUIREMENTS. USing tHE REFERENCE DESIgNS AS A STARTING POINT, THE EFFECTS OF HIGHER POWER LEVELS AND DIFFERING RADIATION REQUIREMENTS AT THE USER OR PAYLOAD PLANE ARE EXAMINED IN TERMS OF CONFIGURATIONAL PARAMETERS, I EE, MASS, FRACTION OF SHUTTLE BAY OCCUPIED, DEPLOYED SIZE, AND SEPARATION DISTANCE OF THE POWER SYSTEM AND PAYLOAD. THE EFFECTS OF ORBITAL ALTITUDE ARE ALSO SHOWN. 
The Requirements described on the following page were deVEloped for the SP-100 REFERENCE DESIGNS AS OF THE END OF 1985. THEY REFLECT A COMPOSITE OF INPUTS FOR POTENTIAL USER MISSIONS. THESE REQUIREMENTS PROVIDE A FRAMEWORK WITHIN WHICH DESIGN CONCEPTS CAN BE EVALUATED.

THE REQUIIREMENTS For the NATURAL ENVIRONMENT ARE GIVEN IN TERMS OF the ORBItAL altitudes for radiation, meteoroids, and DEBris. The extent of the enVironmental effects such as the Van Allen Radiation levels and the mass and SIZE DISTRIBUTION OF METEOROIDS AND DEBRIS PARTICLES ARE SPECIFIED IN THE SP-100 document entitled nuclear Space Power System Preliminary design goals And Requirements, Which has a revision date of December 20, 1984. The worstCASE NATURAL RADIATION ENVIRONMENT IS GIVEN IN NASA TM 82478, WHILE THE METEOROID ENVIRONMENT IS GIVEN IN NASA SP-8013.

EACH USER HAS A SET OF SPECIFIC REQUIREMENTS SO IT IS PROBABLE THAT THESE WILL BE MODIFIED FOR A SPECIFIC APPLICATION. SUCH MODIFICATIONS WILL RESULT IN CONFIGURATIONAL CHANGES THAT, IN TURN, WILL REQUIRE A POWER SYSTEM-USER APPLICATION SYSTEM TRADEOFF STUDY TO DETERMINE THE BEST OVERALL ARRANGEMENT. THIS DOCUMENT GIVES INSIGHT INTO THE EFFECT OF CHANGES IN REQUIREMENTS ON THE POWER SYSTEM. 


\section{REQUIREMENTS FOR SP-100 REFERENCE DESIGN}

1. Electrical power delivered to user: $100 \mathrm{kWE}$ to end of life -

2. LifE: 7 years at FULL POWER; 10 Years TOTAL.

3. MASS OF POWER SYSTEM: <3000 KG INCLUDING DEPLOYABLE BOOM.

4. StOWEd Size limitation: ONE-THIRD OF SHUTtLe bay.

5. USER PLANE (USER AREA SHIELDED FROM RADIATION): $\geq 4.5$-M DISK.

6. RADiation doses at user PLANe for 7-year, FULL-POWER operation:

a. Neutron fluence: 1013 neutrons/cm².

B. GAMMA DOSE: $5 \times 10^{5}$ RADS.

7. NaTURAL ENVIRONMENT (WORST CASE CONDITIONS):

A. Plasma, LOW earth ORBIt OF $500 \mathrm{KM}, 28^{\circ}$ INCLINATION

B. Radiation, 3000-KM altitude at $0^{\circ}$ inCLINATION.

C. Meteoroids, 6000-KM ALtitude, MASS DENSITY OF $0.5 \mathrm{gm} / \mathrm{cm}^{3}$ AND MEAN VELOCITY OF $20 \mathrm{kM} / \mathrm{s}$.

D. DEBRIS, 600- TO 1100-KM ALTITUDE, MASS DENSITY OF

$2.7 \mathrm{GM} / \mathrm{CM}^{3}$ AND MEAN VELOCITY OF $10 \mathrm{kM} / \mathrm{s}$.

8. Capable of achieving full POWER Within 10 hOURS OF Startup. 


\section{SAFETY FEATIIRES}

THE OVERALL SAFETY GOAL FOR THE USE OF NUCLEAR SPACE POWER SYSTEMS IS TO ENSURE THAT RISK TO THE POPULATION AND ENVIRONMENT is acceptably Low, CONSidering the potential benefits. The SP-100 Program is Developing a safety PLan to achieve this goal. The current nuclear safety features of the SP-100 REFERENCE DESIgNS ARE SUMMARIZED ON THE OPPOSItE PAgE WITH RESPECT TO ACCIDENTS, DESIGN REQUIREMENTS, AND ENGINEERED PROTECTION CAPABILITIES. 


\section{SAFETY FEATURES}

1. THE REACTOR WILL REMAIN SUBCRITICAL FOR ALL POSTULATED LAUNCH/ PRELAUNCH ACCIDENTS, REENTRY, GROUND IMPACT, AND SUBSEQUENT IMMERSION IN WATER OR SOIL.

2. REENTRY WILL NOT OCCUR UNTIL RADIOACTIVITY IS SUFFICIENTLY LOW, WITH PROVISION FOR DETECTION AND RECOVERY OF SPECIAL NUCLEAR MATERIALS UPON REENTRY.

3. UNDUE RISK WILL NOT BE TAKEN WITH HAZARDOUS MATERIAL RELEASE UNDER POSTULATED ACCIDENTS.

4. THERE WILI. BE AUTONOMOUS MONITORING OF REACTOR PERFORMANCE FOR A PERIOD OF AT LEAST SIX MONTHS WITH NO INTERACTION FROM GROUND.

5. THERE WILL RE COMMAND RECEPTION CAPABILITY TO ADJUST POWER OUTPUT TO USER NEED.

6. THERE WILL BE SUFFICIENT TELEMETRY TO ENABLE RAPID AND EFFECTIVE USER CONTROL.

7. AN INDEPENDENT ELECTRICAL POWER SOURCE WILL BE PROVIDED FOR REACTOR MONITORING.

8. THERE WILL BE TWO-FAULT TOLERANCE FOR ALL SAFETY-RELATED FUNCTIONS. 
Starting at the forward (Left-hand) End of the deployed CONFiguration, the main

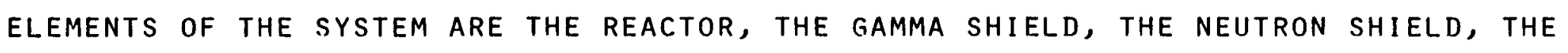

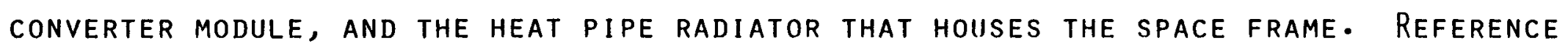
DESIGNS USE A CONICAL RADIATOR DESIGN, ONE OF SEVERAL RADIATOR DESIGNS BEING CONSIDERED.

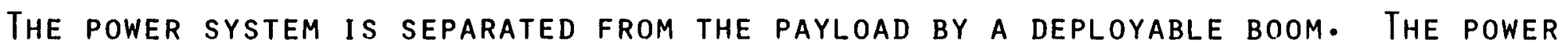
CONDITIONING AND CONTROL MODULE IS LOCATED AT THE PAYLOAD IN THE DEPLOYED CONFIGURATION

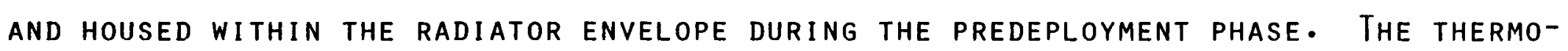
ELECTRIC CONVERTERS ARE ATTACHED TO THE BACK SIDE OF THE RADIATOR.

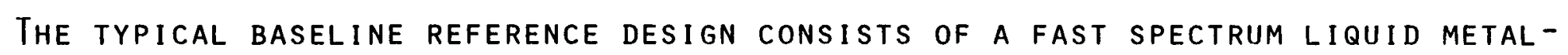
COOLED REACTOR; UN-FUELED, PWC-11 REFRACTORY METAL CLADDING AND STRIICTURE; LITHIUM HYDRIDE-TUNGSTEN RADIATION SHIELD; ELECTROMAGNETIC-PUMPED LIQUID LITHIUM LOOP COUPLED TO A Sige/GAP THERMOELECTRIC POWER CONVERSION SYSTEM $\left(Z=0.8 \times 10^{-3}\right)$; AND A WASTE HEAT REJECTION SYSTEM EMPLOYING heat PIPE RADIATORS. The fallback design uses Sige $(Z=0.7$

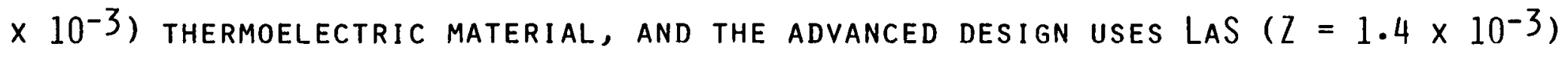
THERMOELECTRIC MATERIAL.

THE REFERENCE DESIGNS MEet THE BASIC REQUIREMENTS OF PROVIDING $100 \mathrm{kWE}$ (END OF LIFE) WITH A MASS OF $3000 \mathrm{KG}$ (2592 KG FOR ADVANCED TO 3292 KG FOR FALLBACK) WHILE

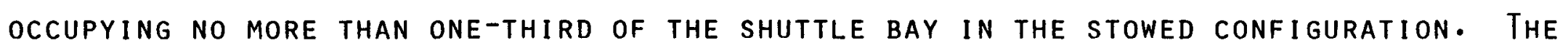
FALLBACK DESIGN REQUIRES A LARGER RADIATOR, WHICH INCREASES ITS DEPLOYED DIMENSIONS. THE ADVANCED DESIGN DOES NOT REQUIRE A DEPLOYED RADIATOR SECTION. ALL THE REFERENCE DESIGNS SATISFY THE REQUIREMENTS ON RADIATION DOSE CHARACTERISTICS IN THE USER PLANE AS GIVEN IN THE FOLLOWING CHART. 
1. POWER:

A. BEgINNING OF LIFE, $105 \mathrm{KWE}$.

B. END OF LIFE, $100 \mathrm{KW}_{\mathrm{E}}$.

2. Life: 7 years full power, 10 years life.

3. MASS: 2592 TO $3292 \mathrm{KG}$.

4. DIMENSIONS

A. Deployed

LENGTH, L: 6.1 TO $11.6 \mathrm{M}$.

DIAMETER, D: 4.3 TO $8.1 \mathrm{M}$.

B. Stowed ( $1 / 3$ of ShuttLe bay)

LENGTH: $6.1 \mathrm{M}$.

DIAMETER : $4.3 \mathrm{M}$.

5. Cone 1/2 ANGLE $\theta: 17$ DEgreEs .

6. Surface temperatures: 783 to $825 \mathrm{~K}$.

7. USER PLANE: 15.5-M DISK AT 25-M SEPARATION.

8. Radiation doses at user plane, 7-year life:

a. Neutron fluence: 1013 neutrons/CM2

B. GaMma dOSE: $5 \times 10^{5}$ Rads.

9. Thermal flux at user Plane: $<0.07 \mathrm{~W} / \mathrm{CM}^{2}$.

10. Reactor thermal power: 1.8 T0 $2.8 \mathrm{MWT}$.

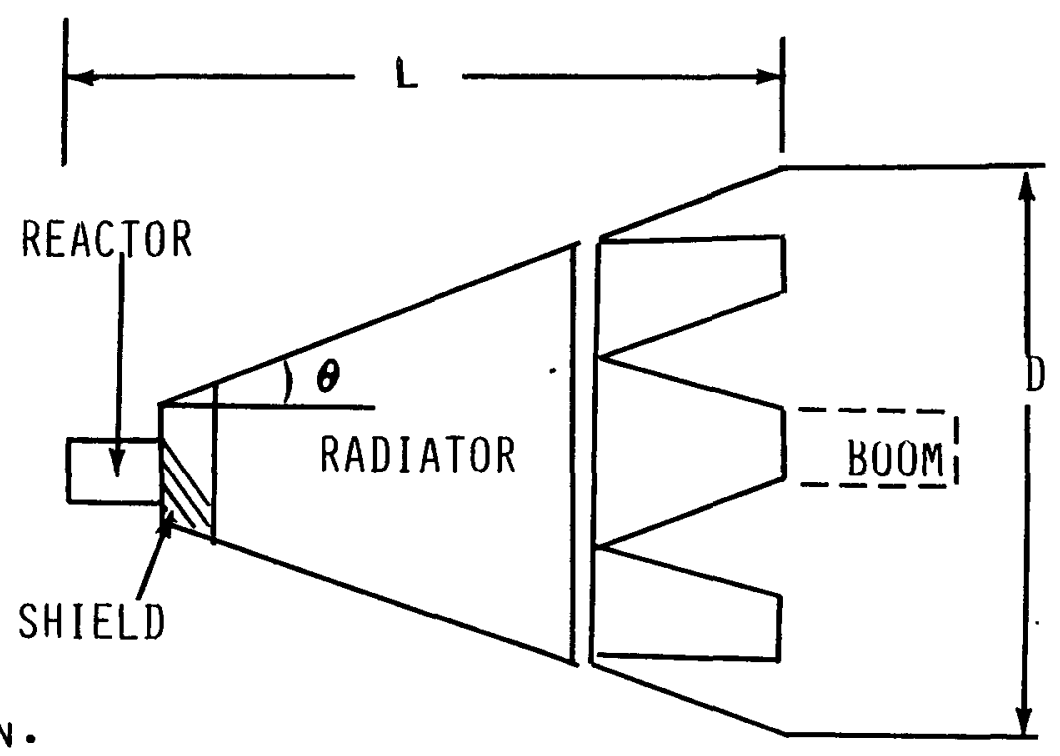

11. Reactor VESSEL HEIGHT: $75 \mathrm{~cm}$.

12. Reactor Vessel diameter: $55 \mathrm{CM}$.

13. 100-KWE SHUNT DISSIPATOR AT THE END OF BOOM.

14. Fixed and Deployable heat PiPE: Radiator area: 56 to $90 \mathrm{~m}^{2}$. 
THIS CHART PRESENTS A SUMMARY OF SYSTEM MASS VERSUS POWER LEVEL FOR THE CONCEPTS (FALLBACK, BASELINE, AND ADVANCED) COMPRISING THE REFERENCE DESIGNS. ONE-MEgAWATt POWER LEVEL IS ACHIEVABLE AT APPROXIMATELY 40 TO 75 W/KG, DEPENDING ON THE adVANCEMENTS IN TECHNOLOGY. THE VARIATION IN SPECIFIC POWER IS DUE TO A VARIATION IN POWER CONVERSION EFFICIENCIES AND HEAT REJECTION DESIGNS.

THE BENEFITS OF SCALE ARE POSSIBLE, PARTIALLY BECAUSE OF REACTOR SCALING EFFECTS WHERE MASS INCREASES SLOWLY WITH POWER LEVELS (BEYOND CRITICAL REQUIREMENTS) FOR THE RANGE OF REACTOR THERMAL POWER FROM 1.8 TO 24 MWT. THIS REACTOR THERMAL POWER RANGE ENCOMPASSES SYSTEM ELECTRICAL POWER LEVELS UP TO 1 MWE. FOR tHE FALLBACK DESIGN, WHICH HAS THE LOWEST POWER CONVERSION EFFICIENCY, SMALL INCREASES IN POWER LEVELS REQUIRE RELATIVELY MODEST MASS INCREASES FOR REACTOR/ SHIELD AND HEAT REJECTION ASSEMBLIES.

The fallback, Baseline, and advanced concepts use Sige $\left(Z=0.7 \times 10^{-3}\right)$, Sige-GAP $\left(Z=0.8 \times 10^{-3}\right)$, AND LAS $\left(Z=1.4 \times 10^{-3}\right)$ THERMOELECTRIC MATERIALs, RESPECTIVELY. DEPENDING ON THE CONCEPT, FOR POWER LEVELS UP TO $280 \mathrm{kWE}$, the REFERENCE DESIGNS USE CONICAL RADIATORS. For hIGHER POWER LEVELS, A MIDCYLINDRICAL SECTION OF INCREASING LENGTH PROVIDES ADDITIONAL HEAT REJECTION AREA. 
SYSTEM MASS VERSIIS POWER LEVEL

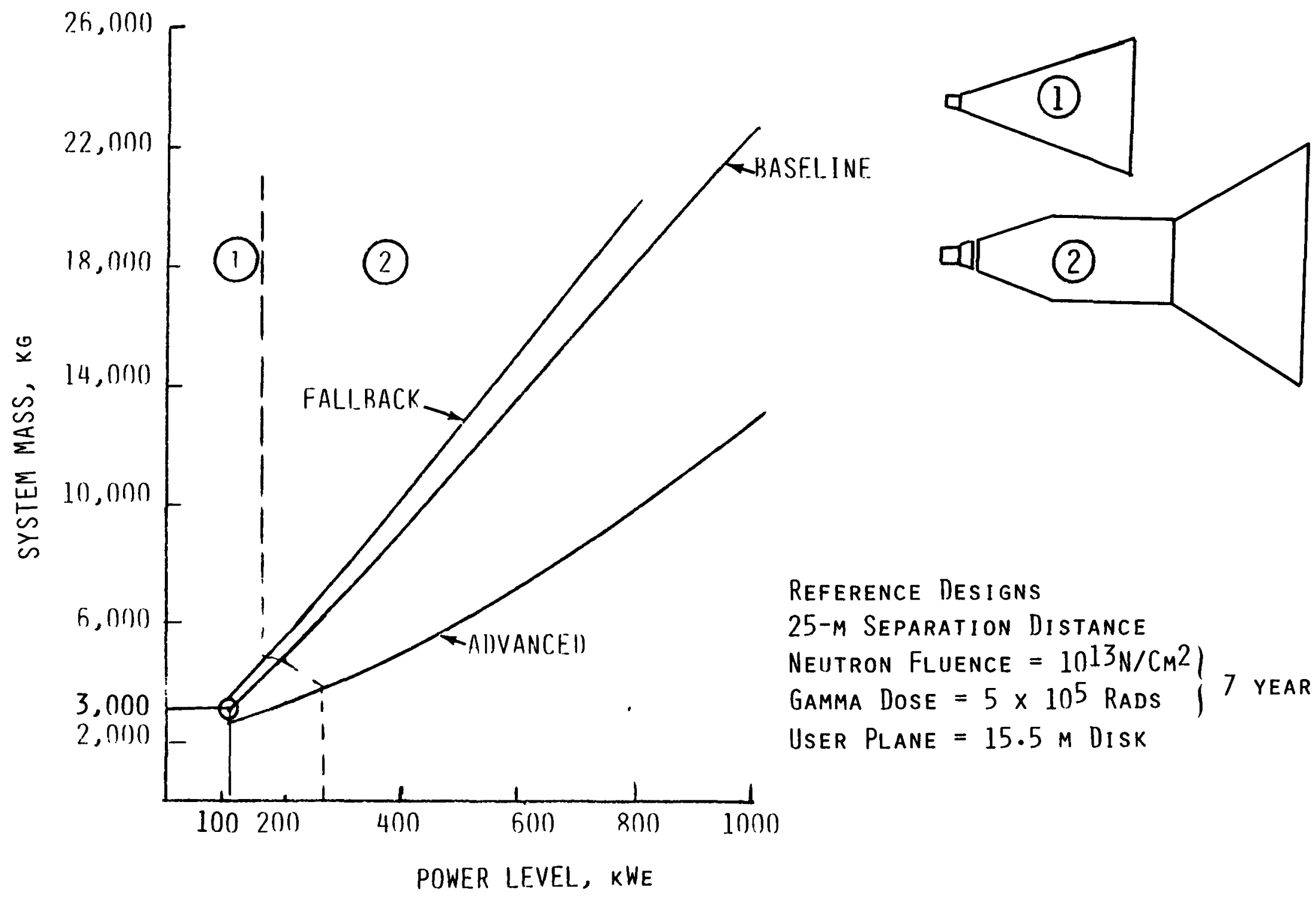




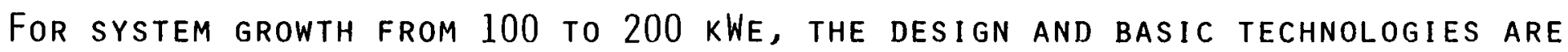
NOT EXPECTED to haVE ANY SIgNIFICANT CHANGES. GROWTH BEYOND 200 KWE REFLECTS

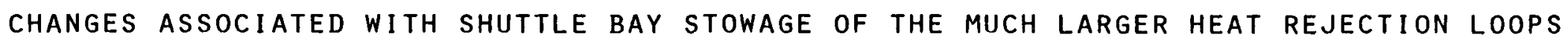

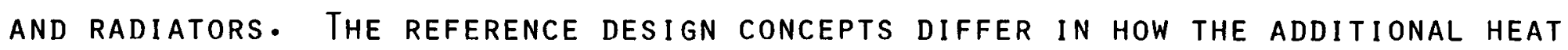
REJECTION RADIATOR PANEL AREAS ARE PROVIDED.

UP TO THE 200-KWE POWER LEVEL, THE REFERENCE DESIGNS DO NOT NEED THE CYLINDRICAL Mid-section. Deployable radiator panels can be designed to fold against the CONICAL FIXED RADIATOR PANELS.

FOR POWER LEVELS OF $300 \mathrm{KWE}$ AND HIGHER, THE MID-CYLINDRICAL SECTION OF INCREASING LENGTH PROVIDES AN ADDITIONAL HEAT REJECTION AREA.

THE PROJECTED AND SURFACE AREAS MAY BE OF INTEREST IN SOME MILITARY APPLICATIONS. THERE IS AN APPROXIMATE SEVEN-FOLd INCREASE IN PROJECTED AND SURFACE AREAS FOR a ten-FOLd POWER LEVEL INCREASE. NOTE that heat is REJECTED FROM BOTH EXTERIOR AND INTERIOR RADIATOR SURFACES WITH A SIGNIFICANT CONTRIBUTION FROM THE INTERIOR PORTION OF THE DEPLOYED RADIATOR. FOR HIGHER POWERS, THE DEPLOYED PORTION FORMS A LARge FRACTION OF THE RADIATOR. THERE IS A RELATIVELY MORE SIGNIFICANT CONTRIBUTION OF THE INTERIOR SURFACE SO THAT THE EXTERIOR SURFACE AREA INCREASES AT A SLOWER RATE FOR HIGHER POWER LEVELS • 


\section{SP-100 PROJECTED AND SURFACE AREAS VERSUS POWER LEVELS}

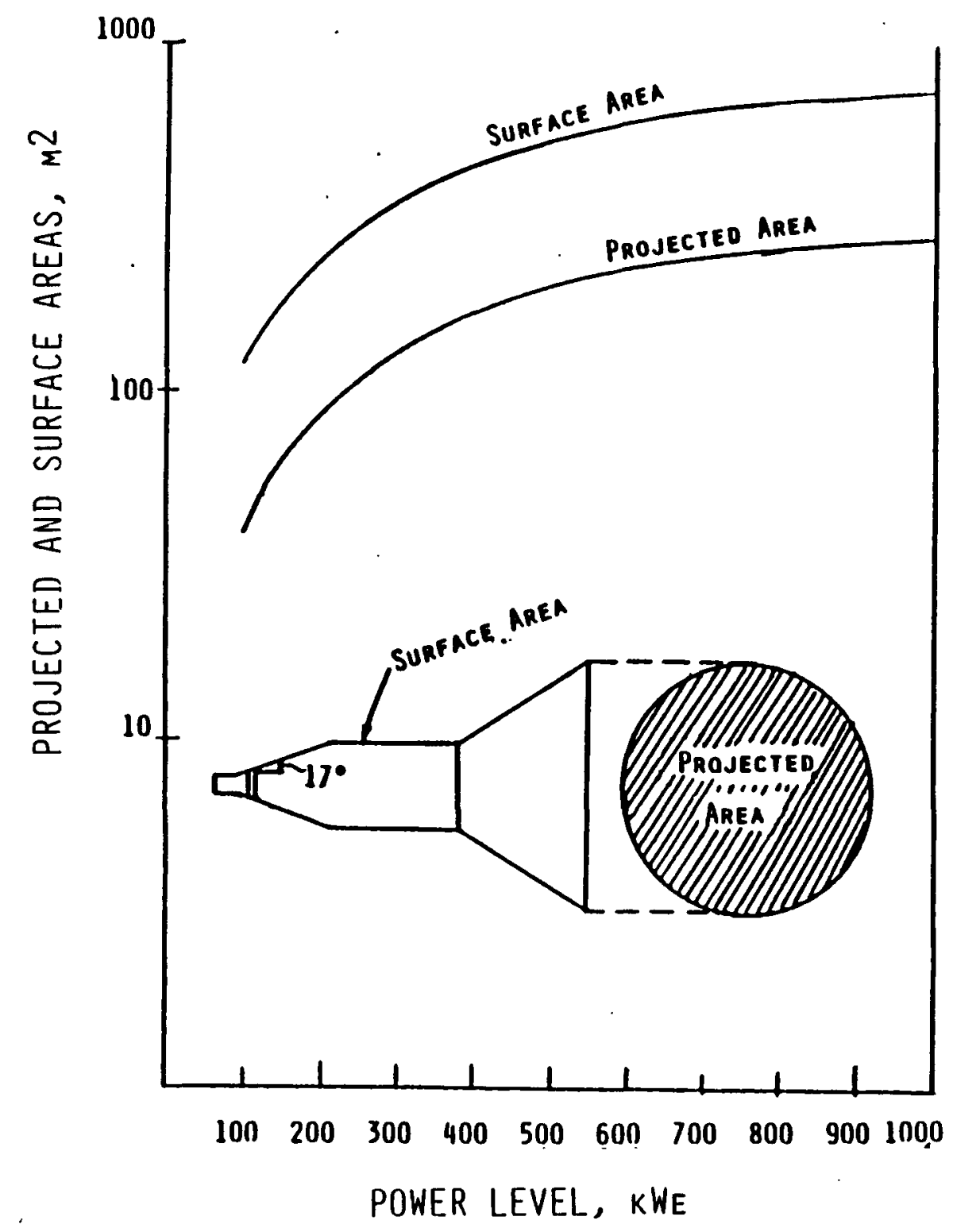

NEUTRON FLUENCE $=10^{13} \mathrm{~m} / \mathrm{cm}$ GAMMA DOSE $=5 \times 10^{5}$ RADS 7 YEAR USER PLANE

$=15.5-\mathrm{m}$ DISK 


\section{SYSTEM STOWED LENGTH VERSIJS POWER LEVEL}

For SYSTEM GROWTH UP TO $200 \mathrm{kWE}$, THE DESIGN AND BASIC TECHNOLOGIES ARE NOt EXPECTED to have any SIgNificant Changes from the 100-kWe design GROWTH FROM 200 TO 1000 KWE REQUIRES SIGNIFICANTLY LARGER HEAT TRANSPORT AND HEAT REJECTION LOOPS, LONGER HEAT PIPE RADIATORS, SCALE-UP OF RADIATION SHIELDS, AND SCALED-UP POWER CONVERSION MODULES.

UP tO A 200-KWE POWER LEVEL, THE REFERENCE DESIGNS USE A CONICAL RADIATOR DESIGN WITH DEPLOYABLE RADIATOR PANELS FOLDED AGAINST THE FIXED CONICAL RADIATOR IN STOWED POSITION.

FOR POWER LEVELS OF 300 KWE AND HIGHER, A FIXED MID-CYLINDRICAL SECTION OF INCREASING LENGTH IS NECESSARY TO PROVIDE AN ADDITIONAL HEAT REJECTION AREA. 
SYSTEM STOWED LENGTH VERSUS POWEK LEVEL

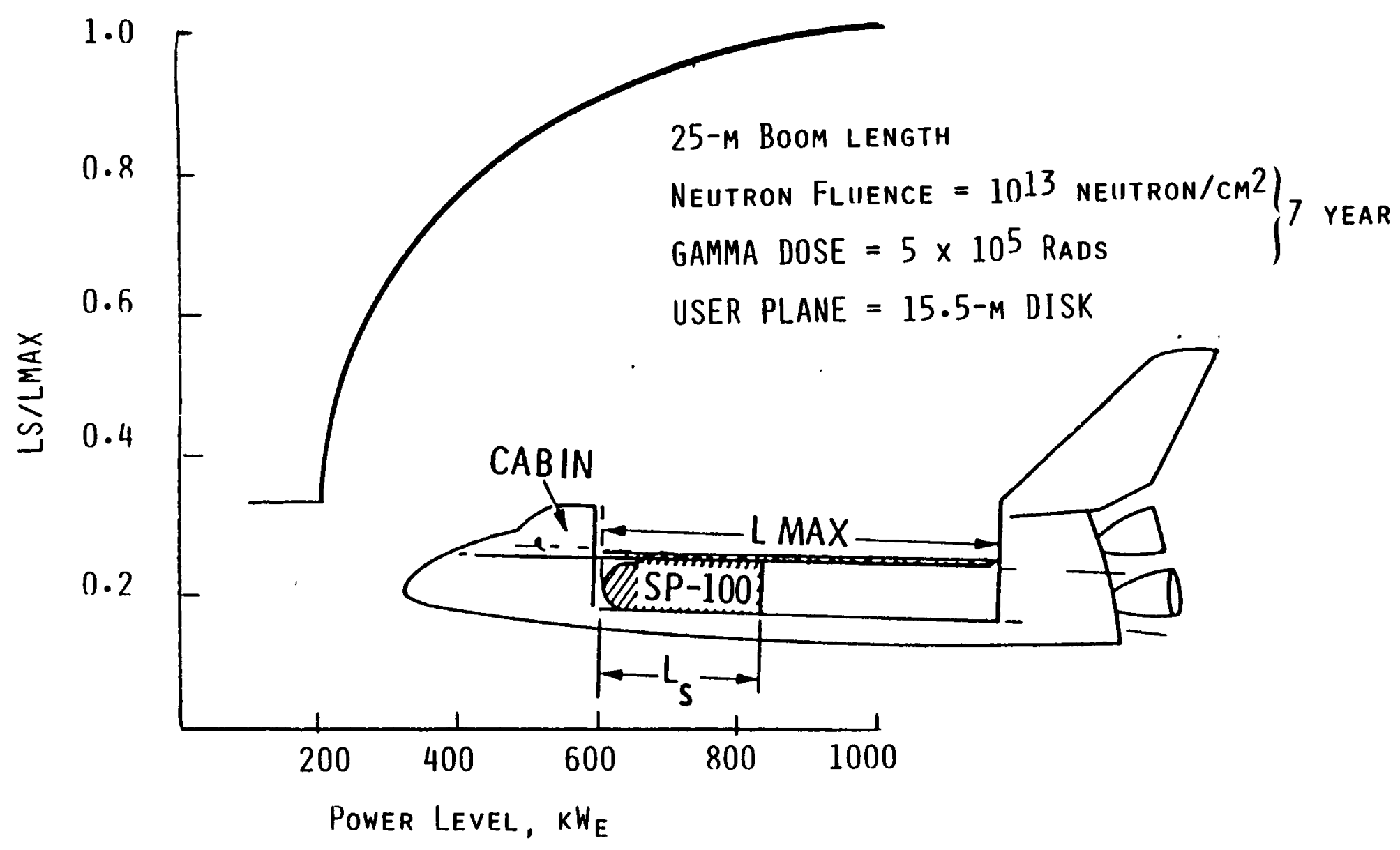


The reference design assumes a user plane disk of $15.5 \mathrm{M}$. As the diameter of

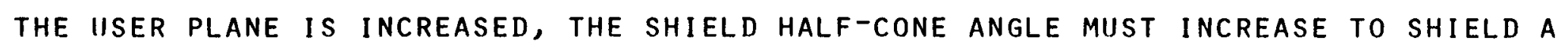
LARGER USER AREA. IT IS EVIDENT THAT LARGE INCREASES IN USER AREA ARE ACHIEVABLE

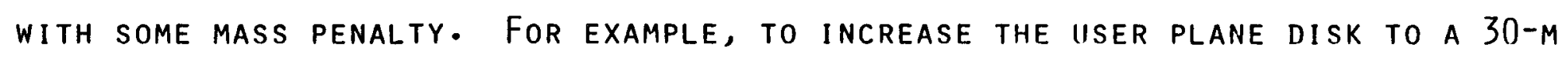
DIAMETER, ONLY A $13 \%$ MASS PENALTY RESULTS.

AS SHOWN BY THE DASHED LINE, SMALL REDUCTIONS OF THE SYSTEM MASS OCCUR IF the USER PLANe diameter is Reduced below the Reference design diameter OF $15.5 \mathrm{M}$. It is nOted that the SP-100 specification Called for a 4.5-M disk diameter. The 15.5-M DISK DIAMETER RESULTED FROM THE CONICAL RADIATOR DESIGNED TO FIT IN

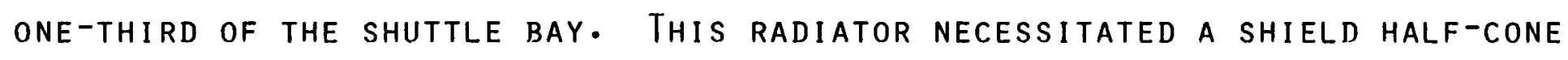
ANGLE OF $17^{\circ}$ CORRESPONDING to THE 15.5-M USER PLANE DIAMETER. USE OF A SMALLER HALF-CONE ANGLE WOULD RESULT IN RADIATION SCATTERING FROM THE RADIATOR INTO THE USER PLANE. 


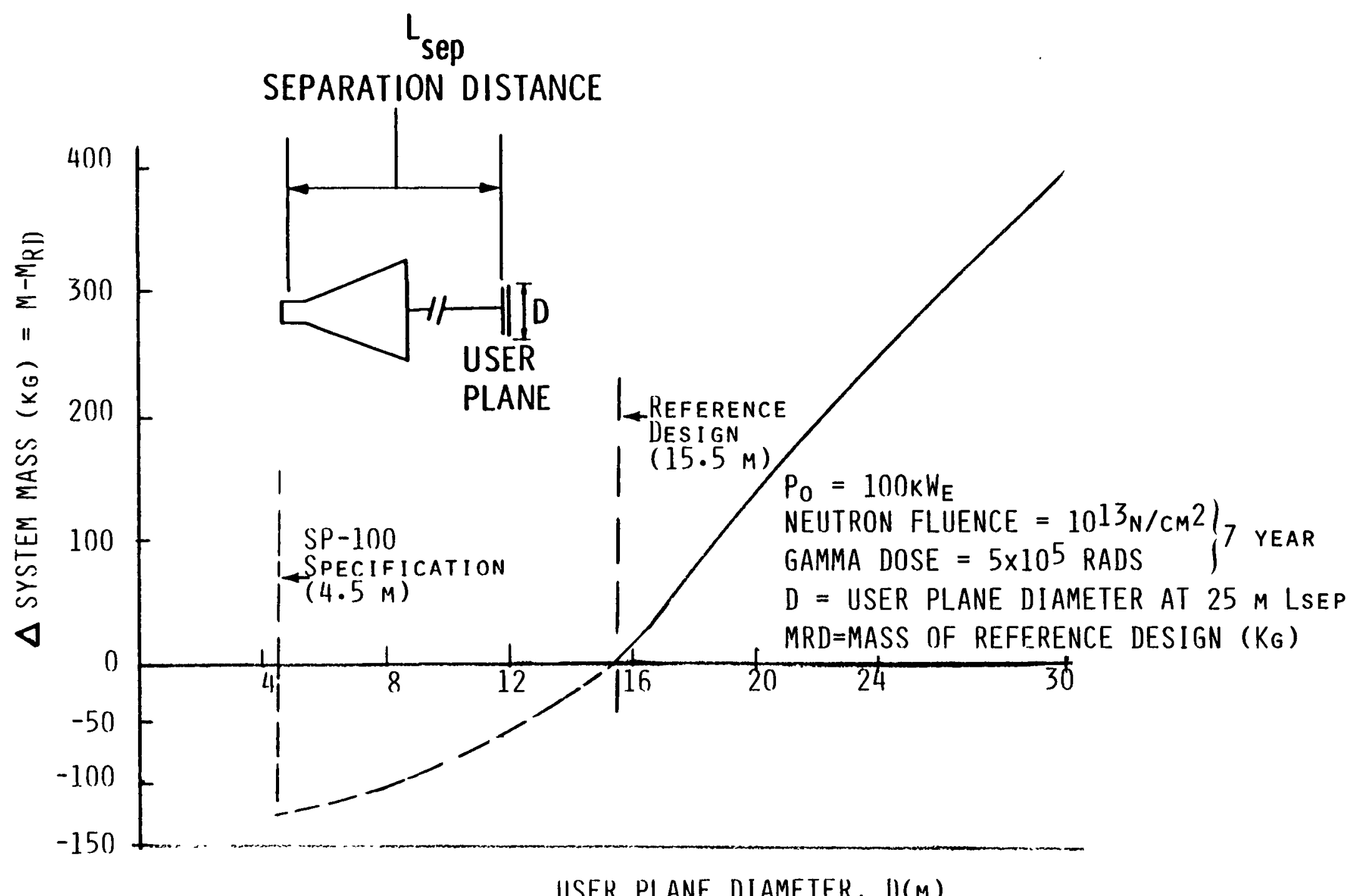


SYSTEM MASS VERSUS GAMMA DOSE REQUIREMENTS

To keep the shield mass to a minimum, a Conical Shadow Shield design is adopted FOR ALL SP-100 CONCEPTS.

The gamma shield material (tungsten) Is much denser than the neutron shield MATERIAL (LITHIUM hydRIDE) SO that the VARIATION IN TOTAL MASS WITH gamMa DOSE IS QUite prominent. There is approximately a $14 \%$ increase in total Mass for a factor OF 10 gaMMa dOSE REDUCTION.

Some electronic devices are extremely Sensitive to gamma Rays (E.g•, COMMERCIAL MOS THAT MAY EXHIBIT SIGNIFICANT DEGRADATION FOR DOSES OF ONLY 104 rads). Hence, the Reference designs locate the power conditioning at the USER PLANE TO MINIMIZE SPOT SHIELDING REQUIREMENTS.

TRADEOFFS OF BOOM SEPARATION DISTANCE, SELECTIVE SPOT SHIELDS, AND DEGREE OF HARDENING OF ELECTRONICS CAN LEAD TO OPTIMIZED SYSTEM MASS CONFIGURATION. 
SYSTEM MASS VERSUS GAMMA DOSE

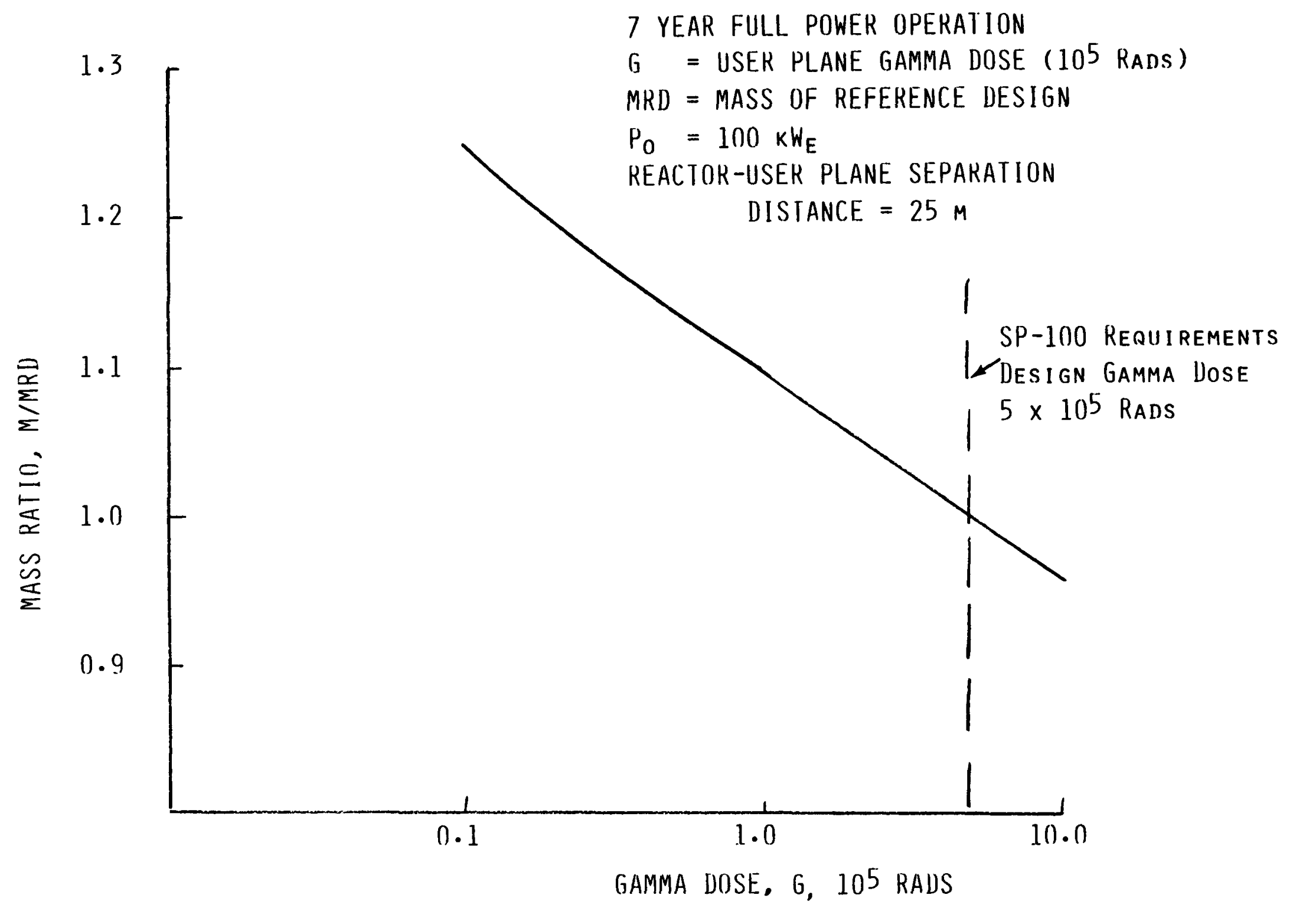




\section{SYSTEM MASS VERSIIS NEIJTRON FLUENCE}

To Minimize shield MASS, the SP-100 SHIELd System COVERs a SMALL SOLID angle ( $17^{\circ}$ half angle) to adequately shadow the dose plane. Such a conical DESIGN FOR THE SP-100 CONFIGURATION PROVIDES AN INVERSE-SQUARE ATTENUATION.

ELECTRONIC EQUIPMENT IS MORE SENSITIVE TO NEUTRONS THAN TO gamMa RAYS BY A FEW ORDERS OF MAGNITUDE WHEN COMPARED ON AN EQUAL ENERGY BASIS •

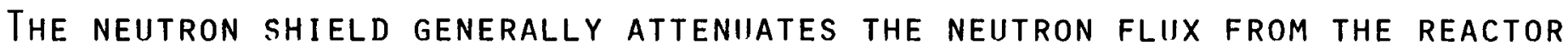
BY A FACTOR OF AT LEAST 104.

The SP-100 system mass is not Very sensitive to the user plane neutron Fluence at a 25-M boOM Reactor-user plane separation distance. There is ONLY A 3\% INCREASE IN SYSTEM MASS, EVEN WHEN THE REQUIRED NEUTRON FLUENCE IS REDUCED BY A FACTOR OF 10 . THE SP-100 MASS IS REDUCED bY APPROXIMATELY $2 \%$ if the user plane neutron fluence can be tolerated at 10 times the design FLUENCE OF $10^{13}$ NEUTRONS/CM2 FOR A 7-YEAR LIFE AT FULL POWER. LiH IS USED AS THE NEUTRON SHIELD MATERIAL BECAUSE OF ITS HIGH HYDROGEN DENSITY AND LOW MASS DENSITY. 


\section{SYSTEM MASS VERSUS NEIITRON FLIIENCE}

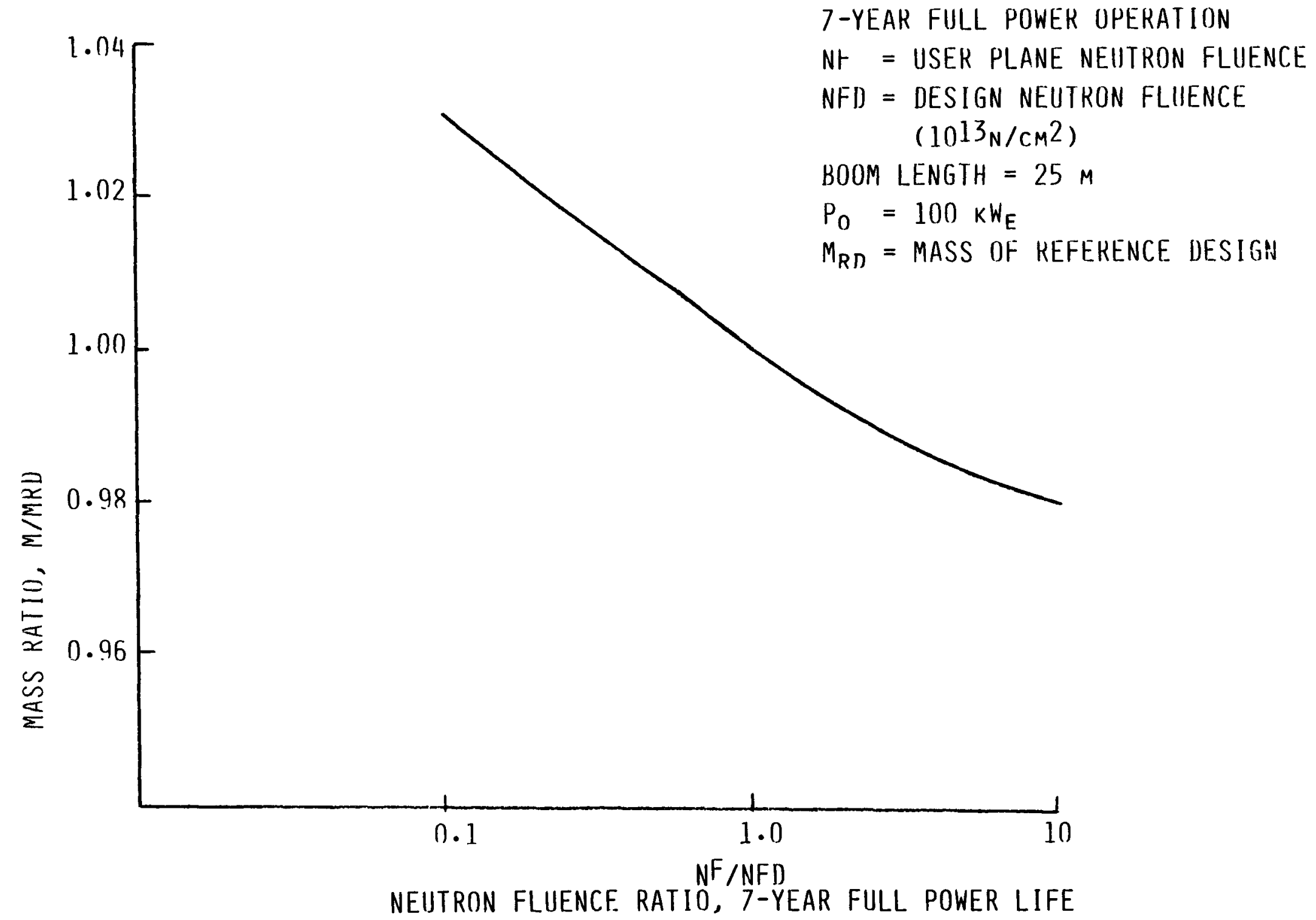


SYSTEM MASS VERSUS REACTOR USER PLANE SEPARATION DISTANCE

A CONICAL DESIGN FOR THE SP-100 SHIELD PROVIDES FOR AN INVERSE SQUARE ATTENIJATION OF REACTOR RADIATION. AS THE REACTOR-USER PLANE SEPARATION DISTANCE IS INCREASED, THE MASS OF THE SHIELD DECREASES RAPIDLY FOR THE SAME tOTAL USER PLANE NEUTRON EFFLUENCE AND gamma DOSE. HOWEVER, the mass OF BOOM STRUCTURE AND POWER CABLES INCREASES WITH ADDED SEPARATION DISTANCE PRELIMINARY ANALYSIS, ASSUMING CONSTANT BOOM MASS PER UNIT LENGTH FOR ALL LENGTHS BEYOND A 25-M SEPARATION DISTANCE, INDICATES THAT A 85- TO 90-M SEPARATION DISTANCE RESIJLTS IN THE LOWEST TOTAL MASS - HOWEVER, MASS SAVINGS BEYOND 50 TO 60 M ARE SMALL; THUS THE MOST DESIRABLE LENGTH WILL DEPEND ON DETAILED TRADEOFFS AND WILL PROBABLY OCCUR IN THE FLAT PORTION OF THE CURVE BEYOND THE KNEE •

The user plane diameter is 15.5 M at a separation distance of 25 M. The SHIELD CONE HALF ANGLE IS FIXED AT $17^{\circ}$. THIS RESULtS IN a VARIATION OF USERPLANE DIAMETER AS Distance inCREASEs. If the SEPARATION DISTANCE WERE REDUCED to $10 \mathrm{M}$, the user plane WOULd be Reduced to a diameter of $6.3 \mathrm{M}$; if the SEPARation distance Were increased to $90 \mathrm{M}$, the user plane diameter would be $55.2 \mathrm{M}$. REQUiREMENTS OF THE USER REgarding the SIZE OF THE USER PLANE WILL BE AN IMPORTANT CONSIDERATION IN SELECTING A DESIRABLE SEPARATION DISTANCE. 
SYSTEM MASS VERSUS REACTOR--USER PLANE SEPARATION DISTANCE

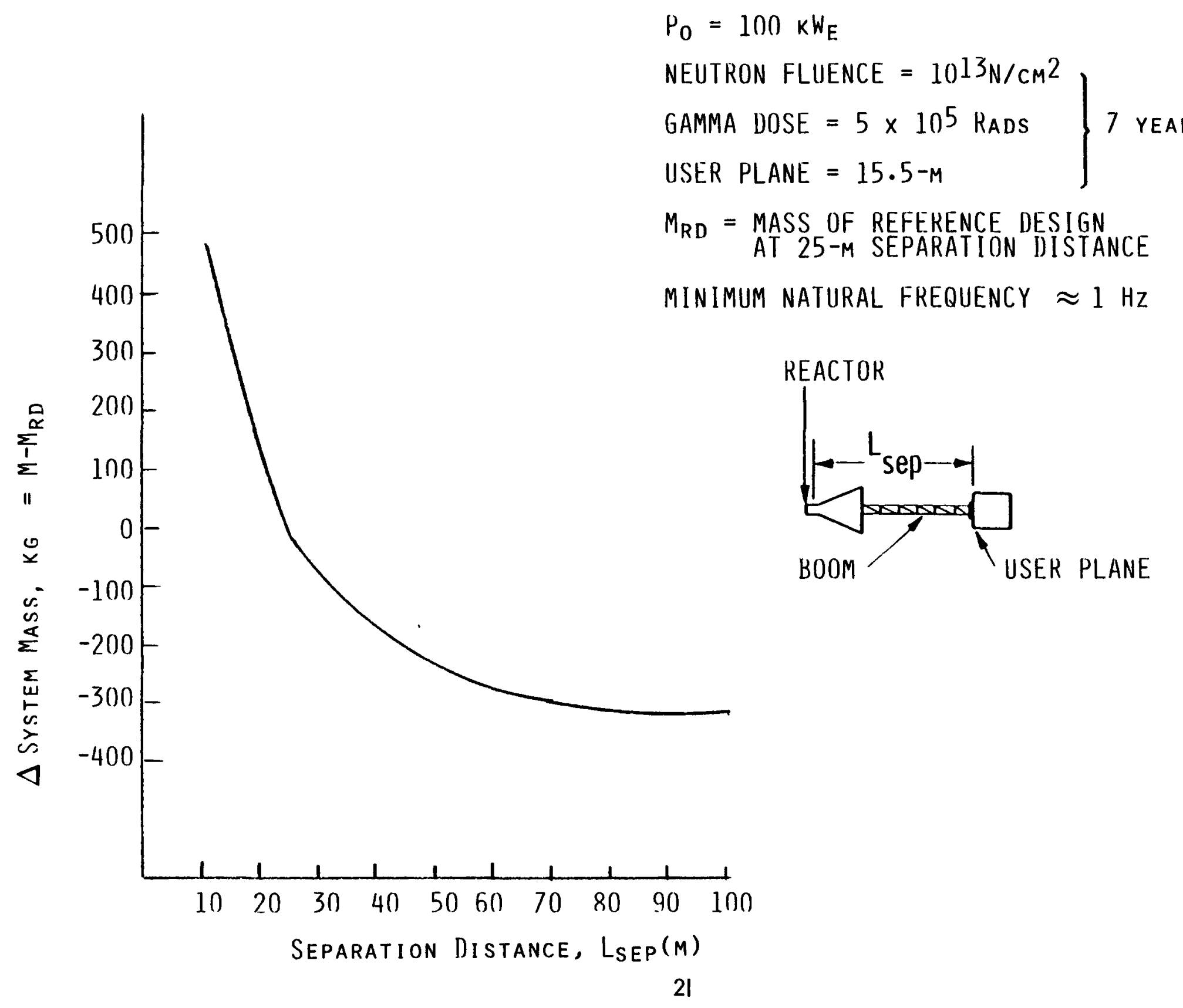


VARIOUS NATURAL AND MAN-MADE ENVIRONMENTS HAVE A SIGNIFICANT IMPACT ON THE SP-100 SYSTEM MASS. THE thrEATS POSED BY METEOROIDS AND THE ORBITAL DEBRIS ENVIRONMENT CAN BE ASSESSED BY CURRENTLY AVAILABLE METEOROID MODELS •

Electronic circuits, because of their nature, tend to be more villnerable to ENVIRONMENTAL EFFECTS THAN MOST SPACECRAFT COMPONENTS. THE MAJOR SOURCES OF NATURAL ENVIRONMENTAL NUCLEAR RAdiation WILL be the EARTH's Van Allen belt elecTRONS AND PROTONS, AND PROTONS AND ALPHA PARTICLES RESULTING FROM SPORADIC SOLAR FLARE RADIATION. THE MOST SEVERE NATURAL NUCLEAR RADIATION ENVIRONMENT IS Estimated to be in a 3000-KM altitude $0^{\circ}$, inCLination Earth ORBit.

MOST HARD ELECTRONICS CAN TOLERATE AND SURVIVE FROM $~ 104$ RADS TOTAL DOSE OF GAMMA, 1010 RADS/S GaMMa DOSE RATE, AND 1012 NEUTRONS/CM2. THIS DEgREE OF HARDNESS REQUIRES ONLY A RELATIVELY SMALL SHIELDING MASS TO WITHSTAND THE MOST SEVERE NATURAL NULLEAR RADIATION ENVIRONMENT.

THEREFORE, THE MASS VARIATION WITH ALTITUDE IS PREDOMINANTLY INFLUENCED BY THE NEED tO PREVENT METEOROIDS AND ORBITAL DEBRIS tHREATS. For the aLtitute RANGe OF 500 TO 1100 KM, THE PROJECTED FLUX OF DEBRIS OBJECTS EXCEEDS THAT OF THE NATURALLY OCCURRING METEOROIDS BY AN ORDER OF MAGNITUDE. THE NEUTRON SHIELD, HEAT TRANSPORT LINES, AND RADIATOR PANELS ARE VULNERABLE TO METEOROID AND DEBRIS PUNCTURES. PROTECTION AGAINST METEOROIDS AND DEBRIS RESULTS IN A MASS INCREASE.

Operating in Low Earth ORbits (LEOS) leads to a potential mass saving because CURRENT SP-100 DESIGN REQUIREMENTS ARE MORE STRINGENT THAN FOR A LEO. THE MASS SAVINGS ARE ASSOCIATED WITH A REDUCTION IN REQUIREMENTS TO PROTECT AGAINST METEOROIDS AND DEBRIS IN A LEO. 


\section{System Mass Versus Operating Altitude}

(Natural Environmental Protection Effects)

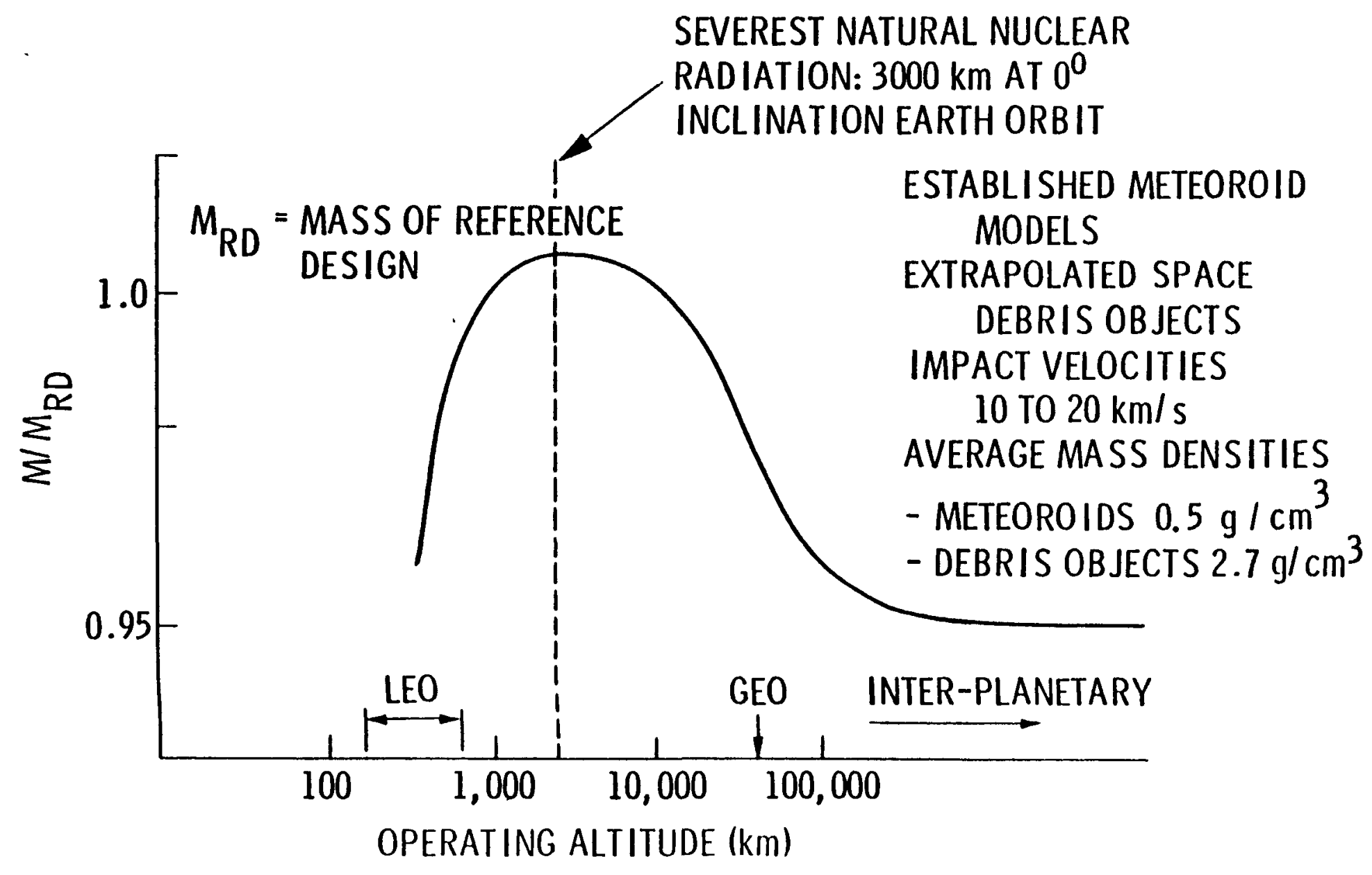

